\title{
ogopaedica
ogziensia
}

$\operatorname{Nr} 3$ (2019)

D0l: http://dx.doi.org/10.18778/2544-7238.03.03

Michalina Biernacka* iD

\section{Fonodydaktyka w kształceniu akademickim przyszłych logopedów i nauczycieli języka polskiego jako obcego/drugiego}

Phonodidactics in academic education of speech therapists and teachers of polish as a foreign/second language

Słowa kluczowe: fonodydaktyka, logopedia międzykulturowa, nauczanie wymowy, język polski jako obcy

Keywords: phonodidatics, intercultural speech-language pathology, teaching pronunciation, Polish as a foreign language

\section{Wprowadzenie}

Oczekiwania, jakie rynek pracy stawia współczesnym humanistom, ewoluują szybciej niż programy nauczania na uczelniach wyższych (por. refleksje Doroty Ciechanowskiej [2014]). I choć zwykle zmiany te nie są możliwe do przewidzenia, to jednak procesy globalizacyjne i powszechne migracje ludności od wielu lat silnie wpływają na rozwój takich dziedzin jak glottodydaktyka polonistyczna (nauczanie języka polskiego jako obcego/drugiego) czy logopedia międzykulturowa. Ze względu na to, że w obszarze zainteresowań obu nauk znajduje się skuteczne porozumiewanie się w języku polskim osób z doświadczeniem migracji, uznano, iż słuszne będzie otwarcie kształcenia przyszłych lektorów i logopedów na możliwości poszerzania wiedzy oraz uzyskiwania praktycznych umiejętności z zakresu fonodydaktyki polonistycznej¹.

Aby sprostać temu zadaniu, od roku akademickiego 2014/2015 autorka niniejszego artykułu proponuje studentom kilku kierunków na Wydziale Filologicznym

\footnotetext{
${ }^{*}$ Uniwersytet Łódzki, Wydział Filologiczny, Instytut Filologii Polskiej i Logopedii, Zakład Lingwistyki Stosowanej i Kulturowej, ul. Pomorska 171/173, 90-236 Łódź, e-mail: michalina.biernacka@uni. lodz.pl, https://orcid.org/0000-0002-2414-9745

1 Termin rozumiany jako metodyka nauczania języka polskiego jako obcego w zakresie podsystemu fonicznego.
} 
Uniwersytetu Łódzkiego zajęcia z fonetyki korektywnej (wcześniejsza nazwa: trudności w nauczaniu wymowy polskiej cudzoziemców). Przedmiot można wybrać w ramach tzw. bloku B (zajęcia do wyboru) zarówno na filologii polskiej (szczególnie cenne dla studentów w trakcie lub po specjalizacji Nauczanie języka polskiego jako obcego/drugiego), jak i na logopedii (z audiologią). Dodatkowo mogą się na nie zapisać studenci z różnych neofilologii, uczęszczający na specjalizację glottodydaktyczną. Co istotne, do roku akademickiego 2018/2019 ani w ramach wspomnianej specjalizacji, ani na logopedii nie ma programowo zagwarantowanych innych zajęć poruszających wspomniane treści, co wpływa na dużą popularność przedmiotu. Nie jest to czymś nietypowym - przegląd programów nauczania różnych polskich uczelni pozwolił ustalić, że nauczanie wymowy polskiej cudzoziemców jest jednym z wielu aspektów poruszanych raczej w trakcie innych zajęć, na przykład z metodyki nauczania (języka polskiego jako obcego), podsystemów języka polskiego (wymowy, pisowni, gramatyki, słownictwa), w zakresie sprawności nadawczych i odbiorczych (m.in. w ramach studiów lub specjalizacji glottodydaktycznych na Uniwersytecie Jagiellońskim, Uniwersytecie Warszawskim czy Uniwersytecie Gdańskim²). Na kierunkach logopedycznych w Polsce fonodydaktyka polonistyczna ani - czego bardziej można by się spodziewać - logopedia międzykulturowa nie są uwzględniane w planach studiów. Trzeba jednak dodać, że logopedia międzykulturowa jest nową ścieżką rozwoju tej interdyscyplinarnej nauki i niewiele jest osobnych opracowań na ten temat ${ }^{3}$. Za główne przyczyny takiego postępowania prawdopodobnie uznać należy brak wykształconej w tym zakresie kadry akademickiej oraz konieczność zmieszczenia wszystkich podstawowych przedmiotów, które według osób odpowiedzialnych za powstanie kierunku studiów pozwalają na uzyskanie kwalifikacji zawodowych. W niniejszym tekście podejmuje się jednak próbę udowodnienia, że w obrębie obu dyscyplin koncentrowanie uwagi przyszłych logopedów i glottodydaktyków na zagadnieniach fonodydaktycznych wzbogaca warsztat zawodowych umiejętności o niezwykle cenne obecnie kompetencje służące pracy z osobami z doświadczeniem migracji, a sam przedmiot - jako niezwykle praktyczny - może skutecznie zachęcić studentów do dalszego rozwoju zawodowego.

Zasadne wydaje się wobec tego odniesienie w tym miejscu do spostrzeżenia Kazimierza Denka, który pisze:

Nasze uniwersytety, aby znaleźć się wśród najlepszych tego typu uczelni w Unii Europejskiej, muszą odpowiedzieć na pytania, jak: zwiększyć odsetek studentów z najlepszymi postępami w nauce oraz zmniejszyć różnice w osiąganych przez nich wynikach; odejść od szablonów;

2 Jako osobny przedmiot wykładane bywało na przykład na Uniwersytecie Marii Curie-Skłodowskiej (nauczanie cudzoziemców wymowy polskiej), Uniwersytecie Śląskim (podstawy fonetyki i poprawnej wymowy polskiej z elementami emisji głosu) czy Uniwersytecie Wrocławskim (nauczanie wymowy polskiej).

3 Mimo wszystko wspomnieć należy ważną pozycję książkową pod redakcją Ewy Czaplewskiej [2018]. 
wzmocnić swoją obecność w naukowych programach europejskich; konfrontować się z nauką światową; prowadzić zajęcia dydaktyczne na najwyższym poziomie w sensie społecznym, merytorycznym, metodycznym i utylitarnym [Denek, 2013, s. 11],

a także do opinii nauczycieli innych języków obcych, którzy doceniają rolę fonodydaktyki [m.in. Szpyra-Kozłowska, 2013] czy też postulatów Speech Pathology Australia, sugerujących powszechną edukację logopedów w kierunku pracy z wielojęzycznymi dziećmi, ich rodzinami i tłumaczami ${ }^{4}$.

\section{Opis zajęć}

Głównym celem proponowanych zajęć było poszerzenie wiedzy słuchaczy o informacje dotyczące sposobów nauczania wymowy różnych osób z doświadczeniem migracji: osób niepolskiego pochodzenia, dzieci dwujęzycznych, dzieci reemigrantów. Sytuacja geopolityczna pokazuje bowiem, że w polskich przedszkolach i szkołach każdego szczebla nieustannie przybywa osób potrzebujących specjalistycznej opieki w zakresie polszczyzny, w tym podsystemu fonicznego (osób, których trudności determinowane są również interferencyjnie). Nadal dość rzadko poloniści bądź neofilologowie mają doświadczenie w zakresie nauczania obcokrajowców, dlatego też coraz częściej placówki próbują zatrudniać nauczycieli, którzy odebrali również wykształcenie glottodydaktyczne czy przeszkolonych międzykulturowo logopedów - zakładając, że rozumieją oni nowe wyzwania i potrafią im sprostać. Warto podkreślić, że choć logopedzi nie są nauczycielami języka polskiego jako obcego, to często mając pod swoją opieką osoby dwu- czy wielojęzyczne (którym przecież też zdarzają się różnego rodzaju zaburzenia mowy), zmuszeni są do zapoznania się między innymi z gramatyką funkcjonalną, aby przekazywanie językowej wiedzy było dostosowane do adresata.

Pierwszy cykl zajęć dla obu kierunków miał charakter pilotażowy, sprawdzano bowiem, jakimi formami pracy da się najlepiej i najskuteczniej przedstawić problemy związane z nauczaniem wymowy cudzoziemców (co początkowo - szczególnie logopedom - jawiło się jako coś niestandardowego). Należało przewidzieć nie tylko zróżnicowany układ i tematykę zajęć (osobno dla filologów i logopedów), lecz również proporcje między teorią a praktyką czy typ zaliczenia na koniec semestru. Czym innym jest bowiem wdrażanie zagadnień fonodydaktycznych na kursach języka polskiego, a czym innym dostosowywanie diagnozy i terapii logopedycznej do potrzeb osób niepolskiego pochodzenia. Mimo różnic w podejściu istotne było jednak takie udoskonalenie samego procesu przekazywania wiedzy, aby tematyka zajęć była dla studentów jak najbardziej interesująca i motywująca do własnych metodycznych

4 https://www.speechpathologyaustralia.org.au/ (za: http://edukacjadwujezyczna.com/). 
odkryć. Niezwykle ważne jest tu zrozumienie, że mimo wszelkich ograniczeń - czasowych, finansowych, lokalowych itp. - praca z osobami z doświadczeniem migracji, której celem jest przeprowadzenie skutecznego treningu fonetycznego, wymaga ogromnego skupienia na jednostce, zindywidualizowania zarówno procesu nauczania, jak i nierzadko samej diagnozy trudności, a generalizacja sposobu postępowania w zasadzie ogranicza się do wprowadzania nielicznych, wyjątkowo lubianych przez metodyka typów ćwiczeń. Niestety, doświadczenia pokazują, że lektorzy języków obcych, także polskiego jako obcego, niechętnie wprowadzają podczas zajęć ćwiczenia fonetyczne, zwykle uznając je za nudne, żmudne lub zbyt czasochłonne. Logopedzi zaś zwykle próbują pozostać przy standardach postępowania, które sprawdzają się w pracy z Polakami. Wobec powyższego stwierdzono, że zapał do wykorzystywania właściwych ćwiczeń percepcyjno-artykulacyjnych należy wzmacniać już na etapie kształcenia akademickiego (nie należy liczyć na jakieś późniejsze szkolenia, w których nauczyciele czy specjaliści mogą przecież nigdy nie wziąć udziału) ${ }^{5}$.

W trakcie kilku lat pracy udało się wyróżnić obligatoryjne treści, które można podzielić na kilka modułów:

Moduł I - System fonologiczny:

- system fonologiczny polszczyzny na tle innych (wybranych) języków świata,

- nieznane/mniej znane głoski, elementy prozodii, układy sylab, zjawiska fonetyczne itp. w innych językach świata (np. mlaski, tony, faryngalizacja, języki gwizdane).

Moduł II - Tzw. miejsca trudne:

- tzw. miejsca trudne w nauczaniu wymowy polskiej cudzoziemców,

- trudności $\mathrm{w}$ zakresie nabywania polskiego systemu, zależne od języka pierwszego uczących się.

Moduł III - Podstawy terminologiczne:

- glottodydaktyczne, np. kompetencja fonologiczna, okres wrażliwy, system foniczny, język pierwszy, drugi, obcy, odziedziczony, fonodydaktyka, fonetyka korektywna, interferencja, zmiana kodów,

- logopedyczne, np. słuch mowny, nawyki artykulacyjne, dentalizacja, kinestezja artykulacyjna.

Moduł IV - Nauczanie wymowy:

- zasady i metody nauczania wymowy języka polskiego jako obcego,

- typy ćwiczeń percepcyjnych i artykulacyjnych (dotyczących prozodii i głosek, grup głosek),

5 Motywacja do uczestnictwa w zajęciach była bardzo różna i choć nie przeprowadzono żadnej ankiety, która mogłaby to sprecyzować, już pierwsze dyskusje na zajęciach wykazały znaczące rozbieżności. Studenci deklarowali zarówno zainteresowanie tematem (np. ze względu na licznych znajomych obcego pochodzenia lub bliskich przebywających za granicą i borykających się z podobnymi problemami w trakcie opanowywania innego języka), chęć pogłębienia wiedzy, jak i zwykłą chęć uzupełnienia punktów ECTS nowym przedmiotem. 
- logopedyczne metody wywoływania, utrwalania i automatyzacji głosek, akcentu oraz intonacji,

- ludyczność w nauczaniu wymowy.

Moduł V - Lapsologia:

- błąd w glottodydaktyce i fonodydaktyce (klasyfikacje błędów, rodzaje, fosylizacja), norma językowa a glottodydaktyczna,

- sposoby korekty (podejścia do zjawiska błędu, przewidywanie błędów, profilaktyka).

Moduł VI - Bilingwizm:

- dwu- i wielojęzyczność;

- nabywanie systemu języka pierwszego i kolejnych, typowe zjawiska językowe towarzyszące wielojęzyczności, niepokojące zachowania językowe,

- opanowywanie języka polskiego jako obcego, drugiego, odziedziczonego i języka edukacji szkolnej.

Moduł VII - Logopedia międzykulturowa:

- diagnoza osób z doświadczeniem migracji,

- planowanie terapii i jej przeprowadzanie.

Różnice między zajęciami dla logopedów i glottodydaktyków dotyczyły zarówno wyboru treści nauczania (spomiędzy zaproponowanych modułów) ${ }^{6}$, jak i sposobu prezentacji poszczególnych zagadnień czy uzupełniania brakującej wiedzy z określonego zakresu. Tematy umieszczono w tekście artykułu zbiorczo, aby łatwiej było uchwycić ich spektrum (jest to i tak pewien wybór, będący efektem kilkuletniej pracy).

Prawidłowa realizacja zadań praktycznych nie mogłaby mieć miejsca, gdyby nie zajęcia teoretyczne - może nieco mniej ciekawe. Niektóre tematy nie wymagały dodatkowego wsparcia uatrakcyjniającego, ponieważ wydawały się interesujące dla wszystkich. Należały do nich tzw. miejsca trudne w zakresie systemu fonicznego polszczyzny, typy ćwiczeń fonetycznych oraz sposoby korekty błędów. Pierwszy z wymienionych tematów dotyczył prezentacji kłopotliwych samogłosek i ich połączeń (system wokaliczny), spółgłosek i ich połączeń (system konsonantyczny) oraz akcentu i intonacji wraz z odstępstwami (system prozodyczny). Same miejsca trudne są o tyle interesujące, że zwykle studenci intuicyjnie podają na przykład wymowę tzw. samogłosek nosowych i dziwią się, że większe kłopoty może sprawiać szereg $[\mathrm{i} / \dot{+} / \varepsilon]$. Egzemplifikacje bywają zaś śmieszne czy dwuznaczne (np. [kurka] zamiast córka, [kJxanka na gas] zamiast kuchenka, [t6ipkJ] zamiast szybko). Sposoby korekty są natomiast wdzięcznym tematem, gdyż za pomocą odpowiednich przykładów łatwo symulować konkretne sytuacje lekcyjne i prosić o wskazanie właściwej reakcji. Jest to temat bliski studentom - zazwyczaj przywołują oni wtedy swoje wrażenia i doświadczenia z lektoratów i innych zajęć przedmiotowych. Wspólna dyskusja

6 Na przykład logopedzi zwykle nie wymagali omawiania metod wywoływania, utrwalania i automatyzacji głosek, akcentu oraz intonacji, a uczestnicy specjalizacji nauczycielskiej nie potrzebowali zajęć na temat diagnozy i terapii logopedycznej. 
z łatwością wyjaśnia, które typy poprawy błędów mogą okazać się najskuteczniejsze (które prowadzą do autokorekty, prowokują do refleksji czy też niewystarczająco angażują uczącego się). Aby ta część zajęć nie była jednak oparta jedynie na dyskusji czy wyliczaniu typów korekty, klasyfikacji błędów bądź samych różnic wynikających z odmienności terminologicznych (np. błąd językowy a błąd wymowy, fonetyczny, artykulacyjny, glottodydaktyczny, interferencja a wymowa nienormatywna), wprowadzano różne ćwiczenie warsztatowe ${ }^{7}$. Są one o tyle ciekawe, że pokazują studentom między innymi trudność, jaką jest szybkie i właściwe zareagowanie na popełniony błąd (choć pracują oni w grupach i mają na to około 10 minut, a nie ułamki sekund).

Omawianie ćwiczeń fonetycznych, a właściwie sprawdzanie ich na sobie, ponieważ studenci wcielali się w rolę obcokrajowców i rozwiązywali zadania, okraszone było często śmiechem, a także słuszną niekiedy krytyką poszczególnych technik. Takie samodzielne przetestowanie zadań pozwalało wczuć się w sytuacje, z którymi na co dzień spotykają się obcokrajowcy, a także dostrzec dobre i złe strony poszczególnych technik. Co więcej, uzmysławiało niektórym, że nie wierzą w skuteczność bądź atrakcyjność jakiegoś typu ćwiczenia i nie powinni - lub przynajmniej powinni z większą ostrożnością - z niego korzystać (np. do powszechnie nielubianych technik należy technika numeru, której stosowanie może okazać się korzystne, lecz jedynie, jeśli prowadzący ćwiczenia nie zniechęci do niej swoim osobistym nastawieniem). Bardzo często słuchacze niemal od razu orientowali się, że niektóre techniki są trudne i mogą zniechęcać (np. ze względu na konieczność nakładania się kilku procesów myślowych podczas ich realizacji, jak wariacje techniki numeru), a inne należy najpierw bardzo dobrze samodzielnie opanować, aby w trakcie zajęć rzeczowo i bez wątpliwości móc z nich szybko skorzystać (m.in. zaczerpnięte z logopedii metody wywoływania dźwięków). Atrakcyjne było również wprowadzanie technik niestandardowych (takich jak rytmogesty i schematy artykulacyjne), zaczerpniętych z metody psychostymulacyjnej Małgorzaty Młynarskiej i Tomasza Smereki [2000], wykorzystywanie elementów programowania neurolingwistycznego (m.in. pisanie historii o głoskach z wykorzystaniem wszystkich zmysłów) czy wprowadzanie elementów wizualizacyjnych, korzystanie z programów bądź platform typu fonem.eu, polfon.upol. cz, wymowapolska.pl.

Jak widać, testowanie rozmaitych technik nauczania, choć oparte na klasyfikacjach i teorii z zakresu glottodydaktyki, jest jednak działaniem praktycznym. Uważa się bowiem, że wyliczanie samych przykładowych technik nauczania nie jest

7 Przykładowo: studenci losowali określone błędy wymawianiowe i musieli na kilka różnych sposobów na nie zareagować (choćby przez przeformułowanie, elicytację, wykorzystanie gestu czy elementu konsternacji), a następnie ustalić najskuteczniejszą reakcję na błąd określonego typu. W tym i wielu innych ćwiczeniach warsztatowych posługiwano się informacjami zgromadzonymi w poradniku metodycznym Znajdź z polskim wspólny język [Biernacka, 2016]. 
wystarczającym sposobem kształcenia przyszłych lektorów czy logopedów. Aby potrafili oni ad hoc w ramach potrzeby zastosować właściwe ćwiczenia, muszą - jeszcze przed fazą praktyk - nauczyć się oceniania ich skuteczności i celowości.

\section{Zadania praktyczne}

Wszystkie tematy zostały tak opracowane, aby na każdych zajęciach studenci mieli okazję obejrzeć i posłuchać (lub tylko posłuchać) określone typy realizacji polskich dźwięków mowy ${ }^{8}$ oraz struktur prozodycznych. Teoria, która stanowi trzon wiedzy potrzebnej do właściwej pracy z cudzoziemcami, bez empirycznego poznania poszczególnych sposobów wymowy, niewiele wnosi w metodyczny warsztat. Trudność stanowi oczywiście praca na nagraniach, ponieważ do tego potrzebne jest odpowiednie wyposażenie techniczne sal, jednak obecnie tego typu argumenty wydają się już niestosowne9. Nie ma wątpliwości, że liczne odsłuchy, do których zachęcani byli studenci (niekiedy wielokrotne wysłuchiwanie jednego wyrazu), najlepiej pokazują, na co warto uczulić ucho, które cechy obcej wymowy są często przesiewane przez sito fonologiczne Polaka i ignorowane, czy też jakie zmiany realizacyjne dość łatwo da się wychwycić audytywnie, a jakie wymagają włączenia percepcji wzrokowej. Warto nadmienić, że wszystkie tego rodzaju ćwiczenia spotykały się z entuzjazmem studentów i mimo znużenia (niekiedy na analizę trzydziestosekundowego nagrania należało poświęcić kilkanaście minut) dawali oni wyraz przekonaniu, że ta część zajęć jest najciekawsza i najwartościowsza. Same nagrania w większości stanowiły archiwum autorki, jednak dostęp do internetu umożliwiał włączanie nagrań dostępnych na YouTubie (np. z programu Europa da się lubić). Najbardziej interesujące okazały się jednak analizy nagrań przynoszonych przez studentów, którzy rejestrowali wymowę swoich znajomych czy członków rodziny mieszkających poza Polską. Największy nacisk położono na analizę wymowy osób angielskojęzycznych (zarówno Brytyjczyków, jak i Amerykanów), niemieckojęzycznych, francuskojęzycznych, hiszpańskojęzycznych (powodem była popularność tych języków i to, że często znane były one uczestnikom zajęć), a także Ukraińców i Wietnamczyków, których dość dużo zamieszkuje województwo łódzkie (a więc potencjalnie większe jest prawdopodobieństwo, że w przyszłej pracy zawodowej studenci będą z nimi pracować).

Oglądanie filmów z udziałem cudzoziemców mówiących po polsku było pierwszym etapem w nabywaniu umiejętności dekodowania zmian artykulacyjnych. Wplecenie w program zajęć elementów fonetyki percepcyjnej zdecydowanie ułatwia pierwszy odbiór: usprawnia proces rozpoznawania różnic - choćby przez możliwość

8 Ze względów stylistycznych terminu używa się synonimicznie do głoski.

9 Co prawda gmach Wydziału Filologicznego Uniwersytetu Łódzkiego jest dobrze wyposażony, w każdej sali są komputer, nagłośnienie i telewizor lub rzutnik, jednak wydaje się, że laptop z głośnikami w warunkach trudniejszej pracy to coś, co zapewne wszędzie da się zastosować. 
antycypowania z kontekstu, sugerowania się mimiką czy gestykulacją, spostrzegania sposobu ułożenia warg czy pracy języka. Kontynuacją procesu rozwoju tych umiejętności były próby dekodowania wymowy i jej zapisu za pomocą alfabetu fonetycznego ${ }^{10}$ wyłącznie ze słuchu. I choć sytuacje takie w zasadzie nieczęsto zdarzają się w codziennej pracy (zwykle, gdy lektor czy logopeda proszeni są o konsultację), pomagają skutecznie uczulić na pewne zjawiska. Należy nadmienić, że przyczyną licznych nagrań tylko do odsłuchu były też uwarunkowania prawne (w autorskim archiwum znajdują się też filmy, których bohaterowie podpisali zgody na odtwarzanie nagrań do celów naukowo-dydaktycznych, nie zgodzili się jednak na pokazywanie samych filmów, twarzy). Atrakcyjne było również słuchanie nagrań, na których ten sam fragment tekstu odczytywany był przez osoby różnych narodowości, a następnie porównywanie popełnianych przez nie błędów. Te ćwiczenia prowadzono na podstawie nagrań zgromadzonych przed kilku laty na potrzeby badań empirycznych do pracy doktorskiej (tekst własny, spreparowany tak, aby zawierał wszelkie trudne polskie głoski i połączenia, a także kłopotliwe prozodycznie wyrazy z różną akcentuacją lub intonacją). Co więcej, wspólnie lub indywidualnie próbowano określać - na podstawie usłyszanych błędów - skąd może pochodzić osoba mówiąca lub jakim językiem pierwszym się posługuje.

Wszystkie te działania miały na celu uruchomienie pewnego nowego sposobu postrzegania błędów u osób wielojęzycznych, po pierwsze - uwrażliwienia na labilność interjęzyka, a po drugie - konieczność zrozumienia, że nie ma stałych czy wręcz skostniałych rozwiązań. Wymowa, zarówno w języku pierwszym, jak i w kolejnych, zależy od licznych czynników, takich jak warunki anatomiczno-czynnościowe, wiek, predyspozycje, motywacja, zdolności, słuch fizjologiczny, muzyczny i mowny, pamięć słuchowa i fonetyczna oraz wiele innych. Nie na wszystkie uczący się ma wpływ, zadaniem nauczyciela lub logopedy (w odpowiednich sytuacjach) jest więc poszukiwanie przyczyn określonych różnic w artykulacji względem rodzimych użytkowników języka i takie zaprogramowanie treningu fonetycznego, aby możliwe było osiągnięcie sukcesu (jeśli jest on możliwy ${ }^{11}$ ). Uważa się bowiem, że rola

10 Zapis wymowy alfabetem fonetycznym to osobny temat, który wart jest rozwinięcia. Z braku miejsca należy jednak wspomnieć choćby to, że na większości polskich uniwersytetów studenci filologii polskiej i logopedii uczeni są wyłącznie zapisu wymowy za pomocą slawistycznego alfabetu fonetycznego - z rzadka studenci logopedii potrafią również zapisywać realizacje zdeformowane [Porayski-Pomsta i wsp., 2013]. I choć to zazwyczaj wystarcza, uważa się, że logopeda, który chce diagnozować i prowadzić terapię osób niejednojęzycznych, a także nauczyciel języka polskiego jako obcego powinni znać przynajmniej podstawy międzynarodowego alfabetu fonetycznego [Rybka, 2015]. Idealna diagnoza (i niekiedy terapia) jest bowiem dwujęzyczna, spostrzeżenia powinny być zaś zapisane tak, aby dało się odnieść je do polszczyzny (porównywanie realizacji w dwóch czy więcej językach ma charakter relacyjny względem polszczyzny), ponadto tylko zapis międzynarodowy jest w stanie skonsultować specjalista od danego języka obcego (także zagraniczny).

$11 \mathrm{~W}$ praktyce zdarzają się różni uczący się, na przykład z doświadczeń autorki przywołać warto Kameruńczyka, który - mimo zgryzu otwartego - niemal wzorcowo realizował wszystkie polskie głoski, a także Hinduski, która ze względu na zbyt krótkie wędzidełko podjęzykowe nie mogła artykułować 
wykładowcy akademickiego nie polega wyłącznie na przekazywaniu skomplikowanej, specjalistycznej wiedzy, ale również na wskazywaniu dróg dalszego rozwoju i krytycznego podejścia do zgromadzonych faktów.

Samo przekazywanie przez pracownika - nauczyciela akademickiego wiedzy studentowi nie wystarcza, aby należycie wykonywać obowiązki dydaktyczne. Chodzi o to, żeby pracownik naukowo-dydaktyczny kreował właściwe relacje uczestników kształcenia, budził w studencie zdolność bycia aktywnym, kreatywnym i innowacyjnym oraz odpowiedzialnym za swe postępy w nauce. W warunkach coraz łatwiejszego i szerszego dostępu do wiedzy bardziej palącą koniecznością niż jej przekazywanie staje się to, gdzie ją znaleźć, spożytkować i pomnożyć. Skoro student ma dostępną w zasięgu ręki wiedzę, to pracownik naukowo-dydaktyczny ma go skłonić do jej poszukiwania, pomóc mu w ocenie, co jest wartościowe, i ją uporządkować [Denek, 2013, s. 11].

\section{Zaliczenie końcowe}

Wymienione zadania, które studenci mieli wykonywać w trakcie całego semestru zajęć (a także inne, których nie sposób wymienić ze względu na ograniczenia tekstu), prowadziły do końcowego zaliczenia. W ciągu kilku lat sposób zaliczenia przedmiotu kilkakrotnie się zmieniał, natomiast efekt uzyskany w roku akademickim 2018/2019 zdaje się wreszcie optymalny. Nie zdecydowano się na żaden test, ponieważ zajęcia z założenia miały być praktyczne i warsztatowe, a teoria to podwalina wiedzy opanowanej i weryfikowanej za pomocą oceny poszczególnych umiejętności ${ }^{12}$. Konspekt zajęć fonetycznych też nie byłyby dobrym pomysłem, gdyż nie wszyscy studenci ukończyli specjalizację Nauczanie języka polskiego jako obcego/drugiego, a więc nie wiedzieli, jak tego rodzaju scenariusze pisać. Poza tym w trakcie semestru wielokrotnie udowadniano, że systematyczne i konsekwentne ćwiczenie słuchu i artykulacji przez kilka do kilkunastu minut podczas każdej lekcji13 daje lepsze rezultaty niż półtoragodzinne spotkania odbywane co jakiś czas (zwykle nie ma na nie czasu, szkoły nie uwzględniają ich w programach nauczania, a lektor nie chce przez całe lekcje ćwiczyć wymowy, gdyż nie wie jak - nie wspominając o tym, że takie zajęcia bywają po prostu męczące dla obu stron i są niekiedy trudniejsze do przygotowania).

większości spółgłosek (nie tylko dentalizowanych) wyłącznie w języku polskim, po angielsku - dzięki wieloletnim kompensacjom - brzmiała jak rodowita Brytyjka.

12 Przykładowo autorce zajęć zależało na sprawdzeniu, czy student wie, z jakimi trudnościami zwykle mierzą się konkretne narodowości, czy potrafi zaprogramować odpowiedni trening fonetyczny, uwzględniając zarówno percepcję, jak i artykulację, czy wie, jak stymulować rozwój mowy dzieci bilingwalnych czy też w jaki sposób i na jakim poziomie reagować na poszczególne błędy wymowy.

13 Wbrew powszechnym opiniom praca logopedy jest wielotorowa, nie zajmuje się on wyłącznie ćwiczeniami artykulacji, stąd i dla tych studentów taki sposób zaliczenia nie był odpowiedni. 
Ostatecznie postanowiono, że zaliczenie będzie mieć charakter dwuetapowego projektu, wymagającego od studentów zastosowania wiedzy z zajęć i odrobiny kreatywności. Pierwszym zadaniem było, po wylosowaniu jakieś trudności fonetycznej (np. zamiana głoski [s] na [s], zachowywanie dźwięcznego wygłosu obstruentów, stała akcentuacja oksytoniczna), ustalenie, dla jakich narodowości może być kłopotem (i wyjaśnienie dlaczego), a następnie samodzielne wymyślenie co najmniej dwóch różnych ćwiczeń percepcyjnych i dwóch różnych ćwiczeń artykulacyjnych, które mogłyby w danym zakresie usprawnić wymowę obcokrajowców. Drugie zadanie polegało na zdobyciu minutowego nagrania cudzoziemca mówiącego po polsku (studenci mogli korzystać z internetu lub przygotować własne nagrania), sporządzeniu transkrypcji tekstu dowolnym alfabetem fonetycznym, a następnie ocenienie realizacji i opisanie zjawisk fonetycznych, do których najczęściej dochodziło w trakcie wypowiedzi (określenie, co wymagałoby ćwiczeń).

Prace końcowe były na bardzo różnym poziomie, lecz ogólnie uznać trzeba, że wszyscy wykazali się zaangażowaniem, a niektórzy wręcz niesamowitą pomysłowością (wymyślano krzyżówki słowne i obrazkowe, wierszyki czy zadania wykorzystujące ruch). Ocena prac była trudna, ponieważ wymagała wiele czasu. Jednak wysiłek, jaki studenci musieli włożyć w proces przygotowania projektu, wart był podjęcia decyzji o działaniowej formie zaliczenia.

\section{Zakończenie}

Jak już wspomniano, nie dość wyraźne eksponowanie zagadnień fonodydaktycznych na specjalizacjach z nauczania języka polskiego jako obcego czy kierunkach logopedycznych nie wynika $z$ ignorowania problemów, jakie determinuje niepoprawna artykulacja, lecz zwykle jest efektem braków kadrowych i dopasowywania się do ograniczonej liczby przedmiotów (a co z tego wynika i punktów ECTS), które zrealizować mogą/muszą studenci. Warto więc podkreślić, że tekst nie ma na celu krytykowania osób odpowiedzialnych za poszczególne specjalizacje czy kierunki na polskich uczelniach ${ }^{14}$, sugeruje jednak rozwój akademików również w tym zakresie, aby kształcenie nowych glottodydaktyków i logopedów odpowiadało na aktualne potrzeby.

Warte uwagi wydało się więc naświetlenie problemu, jakim jest brak długofalowego kształcenia w zakresie fonodydaktyki (przykładowo: dwoje zajęć w ramach przedmiotu metodyka nauczania języka polskiego jako obcego daje jedynie możliwość przybliżenia podstawowych zagadnień). Wydaje się też, że braki w kształceniu akademickim w tym zakresie to jedna z przyczyn, dla których lektorzy języka polskiego jako obcego tak często po macoszemu traktują trening fonetyczny w swojej

14 Autorka, jako opiekun specjalizacji na Uniwersytecie Łódzkim, zdaje sobie sprawę z możliwości i wyzwań organizacyjnych. 
praktyce zawodowej (albo wcale takich ćwiczeń nie wprowadzają, uznając, że postępy w wymowie są efektem zalania językiem i nie trzeba poświęcać na to czasu, albo korzystają jedynie z ćwiczeń dostępnych w podręcznikach kursowych - zwykle dobrych, acz niewystarczających ${ }^{15}$ ). Logopedzi zaś - mimo systematycznie rosnącej liczby dzieci i dorosłych wielojęzycznych, którzy pojawiają się w gabinetach - niewystarczająco zapoznani są z różnicami między akwizycją języka a uczeniem się polskiego jako obcego bądź też zbyt wielką wiarę pokładają w jednojęzycznej (polskiej) diagnozie. Jest to temat niezwykle ważny, coraz częściej podkreślany również przez polskich badaczy (analiza błędów powinna być międzyjęzykowa, aby ustrzec się przed ewentualnymi nieprawidłowościami w diagnozie ${ }^{16}$ ). Co więcej, wiedza z zakresu fonodydaktyki może być również wykorzystana poza Polską, choćby dlatego, że Polacy coraz częściej migrują i zdarza się, iż przebywając w innych krajach, potrzebują specjalistów (tak też rozwijają się popularne dziś kursy językowe oraz diagnozy i terapie logopedyczne online).

Istotne jest więc otrzymanie szansy na zdobycie choćby podstawowej wiedzy i umiejętności przed rozpoczęciem praktyki. Sytuacja, w której młody lektor trafia w grupie studentów na kilka osób obarczonych znacznymi trudnościami w opanowywaniu wymowy i przez długi czas nie widzi postępów ani nie potrafi zrozumieć najprostszych wypowiedzi, jest naprawdę trudna. Podobnie logopeda, który nie jest w stanie ocenić, czy popełniane błędy są rezultatem interferencji, czy też głoski w języku polskim są deformowane, może czuć się zdezorientowany i popełniać strategiczne błędy w diagnozie i terapii, przez co również nie będzie skuteczny. Aby uchronić specjalistów przed błędami, których skutki odczuwać będą uczący się czy pacjenci, należy więc działać zawczasu i zadbać o odpowiednio sprofilowaną edukację. Tym bardziej cieszy fakt, że są takie uczelnie w Polsce, które uwzględniają fonodydaktykę w podstawie programowej studiów/specjalizacji glottodydaktycznych, a także że na Uniwersytecie Łódzkim możliwość taką otrzymują również studenci logopedii.

15 Coraz więcej jest publikacji, z których można w tym zakresie korzystać. Należą do nich zarówno poradniki dla lektorów i logopedów [Karczmarczuk, 1987; Tambor, Maciołek, 2012; Biernacka, 2016], jak i podręczniki pełne ćwiczeń [Madelska, 2010; Majewska-Tworek, 2010; Kołaczek, 2017; Bednarska-Adamowicz, Dembińska, Małyska, 2019]. Podręczniki kursowe w tym aspekcie powinny stanowić jedynie pierwsze źródło podstawowych ćwiczeń, przyświeca im bowiem zwykle podejście uniwersalistyczne i nie uwzględniają błędów interferencyjnych, charakterystycznych dla poszczególnych (różnych) narodowości.

16 Zdarza się, że diagnozowane są jakiegoś typu zaburzenia mowy, podczas gdy w mowie dziecka dwujęzycznego zachodzą zmiany charakterystyczne dla osób dwujęzycznych (np. zmiany kodów). Bywa i odwrotnie, przykładowo: dziecko ma zaburzenia fonologiczne lub deficyty słuchu, a jego wymowa oceniana jest jako poprawna, aczkolwiek kształtująca się (za źródło błędów podawana jest wielojęzyczność). 
Literatura

Bednarska-Adamowicz K., Dembińska K., Małyska A., 2019, Łatwo ci mówić! Ćwiczenia fonetyczne dla obcokrajowców uczących się języka polskiego, Warszawa: Start Polish.

Biernacka M., 2016, Znajdź z polskim wspólny język. Fonetyka w nauczaniu języka polskiego jako obcego, Łódź: Wydawnictwo Uniwersytetu Łódzkiego.

Ciechanowska D., 2014, Akademickie ksztatcenie pokolenia $Y$ w perspektywie zmian $w$ dydaktyce szkoły wyższej, [w:] Ciechanowska D. (red.), Perspektywy zmian w praktyce kształcenia akademickiego, Szczecin: Oddział Regionalny Towarzystwa Wiedzy Powszechnej, s. 177-195.

Czaplewska E. (red.), 2018, Logopedia międzykulturowa, Gdańsk: Wydawnictwo Harmonia.

Denek K., 2013, Uniwersytet. Między tradycją a wyzwaniami współczesności i przyszłości, „Edukacja Humanistyczna", nr 1(28), s. 7-21.

http://edukacjadwujezyczna.com (dostęp: 10.07.2019).

http://fonem.eu (dostęp: 10.07.2019).

http://polfon.upol.cz (dostęp: 10.07.2019).

https://www.speechpathologyaustralia.org.au (dostęp: 10.07.2019).

http://wymowapolska.pl (dostęp: 10.07.2019).

Karczmarczuk B., 1987, Wymowa polska z ćwiczeniami, Lublin: Wydawnictwo Polonia.

Kołaczek E., 2017, Testuj swój polski - Fonetyka, Kraków: Wydawnictwo Prolog.

Madelska L., 2010, Posłuchaj, jak mówię (Podręcznik ucznia; Poradnik dla rodziców i nauczycieli; Film dydaktyczny). Materiały do ćwiczenia słuchu i wymowy dla dzieci oraz dla dorosłych, uczących sięjęzyka polskiego jako obcego, Wiedeń: Artjam-studios.

Majewska-Tworek A., 2010, Szura, szumi i szeleści. Ćwiczenia fonetyczne nie tylko dla cudzoziemców, Wrocław: Oficyna Wydawnicza Atut.

Młynarska M., Smereka T., 2000, Psychostymulacyjna metoda kształtowania i rozwoju mowy oraz myślenia, Warszawa: Wydawnictwa Szkolne i Pedagogiczne.

Porayski-Pomsta J., Kwasiborska-Dudek J., Jauer-Niworowska O., Lipiec D., Więcek-Poborczyk I., Golanowska M., Malinowska A., 2013, Znaki fonetyczne do zapisu poprawnych i zdeformowanych realizacji fonemów języka polskiego w alfabetach międzynarodowym i slawistycznym, Gdańsk: Przedsiębiorstwo Glottispol.

Rybka P., 2015, Międzynarodowy alfabet fonetyczny w slawistyce, Katowice: Wydawnictwo Uniwersytetu Śląskiego.

Szpyra-Kozłowska J., 2013, Sukcesy i porażki fonodydaktyki języka polskiego jako obcego. Uwagi postronnej obserwatorki, „Poradnik Językowy”, nr 2, s. 7-21.

Tambor J., Maciołek M., 2012, Głoski polskie. Przewodnik fonetyczny dla cudzoziemców i nauczycieli uczacych języka polskiego jako obcego, Katowice: Wydawnictwo Uniwersytetu Śląskiego. 


\section{Streszczenie}

Celem artykułu jest wykazanie istotnych treści nauczania z zakresu fonodydaktyki polonistycznej, które - jak się uważa - powinny być obowiązkowe na takich kierunkach lub specjalizacjach, jak nauczanie języka polskiego jako obcego/drugiego czy logopedia. Przeobrażający się świat i coraz większa liczba osób wielojęzycznych w Polsce determinują określone zmiany w programach nauczania, które uwzględniają pracę z osobami z doświadczeniem migracji. Na przykładzie autorskich zajęć wymienia się te zagadnienia, które w opinii autorki tekstu powinny być omawiane w trakcie studiów, aby uchronić adeptów obu dyscyplin przed popełnianiem błędów podczas praktyki zawodowej.

\section{Abstract}

The aim of this paper is to show relevant teaching topics of Polish language phonodidactics, which, as it is believed, should be obligatory in such majors or specializations as teaching Polish/second language to foreigners or speech-language pathology. The changing world and the growing number of multilingual people in Poland determine specific changes in universities that include work with people with migration experience. The issues in question should be discussed during the course of studies in order to prevent students of both disciplines from making mistakes during their professional practice. 